\title{
Perancangan dan Analisa Pengereman Dinamis dengan Metode Kombinasi Capacitor Self Exitation dan Zero Sequence Braking pada Motor Induksi 3 Fasa
}

\author{
Prian Gagani Chamdareno ${ }^{1}$, Sudibyo Yakti Pangestu ${ }^{2}$ \\ Teknik Elektro Universitas Muhammadiyah Jakarta \\ Jl. Cempaka Putih Tengah 27 No 47 \\ Email: ${ }^{1)}$ prian.gagani@ftumj.ac.id, ${ }^{2)}$ sudibyoyp@gmail.com
}

\begin{abstract}
ABSTRAK
Salah satu hal penting pada motor induksi tiga fasa dalam suatu industri adalah pengereman. Dibutuhkan waktu cepat untuk menghentikan motor guna menghindari hal-hal seperti saat terjadi kecelakaan kerja atau terdapat kerusakan pada motor. Pengujian ini menggunakan alat pengereman yang dirancang untuk mendapatkan perbandingan hasil dari pengereman motor induksi 3 fasa. Dari hasil pengujian yang didapat, penggunaan kombinasi dua metode dapat menghentikan motor lebih cepat. Hasil percobaan yang dilakukan dengan metode Capacitor Self Exitation waktu berhenti motor tercepat adalah menggunakan kapasitor $50 \mu F$ dibutuhkan waktu 11.5 detik. Kemudian menggunakan metode Zero Sequence Braking waktu berhenti tercepat adalah inject tegangan AC 262 volt dengan waktu 9.9 detik. Dan terakhir dengan mengkombinasikan dua metode yaitu menginject tegangan AC dan menggunakan kapasitor. Hasilnya dengan waktu berhenti tercepat adalah inject tegangan 264 volt dan kapasitor $50 \mu \mathrm{F}$ dapat menghentikan motor lebih cepat yaitu 6,1 detik.
\end{abstract}

Kata Kunci : pengereman, capacitor self exitation, zero seqence braking, kombinasi

\begin{abstract}
One of the most important things in a three-phase induction motor is a braking. It takes fast time to stop a three phase induction motor to avoid things like work accidents or damage to the induction motor. This research uses braking that is made to get a comparison of the results of braking. The results obtained, braking a combination of two methods can stop the three-phase induction motor faster. The results of experiments conducted with the Capacitor Self Exitation method to stop the fastest induction motor using a 50 $\mathrm{F}$ capacitor takes 11.5 seconds. Then using the Zero Sequence Braking method the fastest stop time is inject AC voltage of 262 volts with a time of 9.9 seconds. And finally by combining two methods, namely injecting AC voltage and using a capacitor. The result with the fastest stopping time is an inject voltage of 264 volts and a 50 $\mu F$ capacitor can stop the motor faster at 6.1 seconds.
\end{abstract}

Keywords: braking, capacitor self exitation, zero sequence braking, combination

\section{PENDAHULUAN}

Pada penggunaannya, dalam industri salah satu parameter kontrol yang terpenting dari motor induksi tiga fasa adalah pengereman. Dimana pengereman sangat dibutuhkan ketika sistem yang sudah dibuat harus melakukan proses berhenti, baik ketika motor selesei digunakan maupun ketika terjadi kesalahan pada sistem untuk mengamankan motor yang sedang bekerja [1]. Pengereman mesin secara elektrik pada mobil listrik perlu dilakukan untuk menjaga keamanan mobil tersebut bila dikendarai [2]. Pengendalian motor induksi pada saat pengereman, diperlukan sistem pengendali yang handal, efektif, efesien dan dapat bekerja secara terus-menerus [3].

Pada dasarnya, sistem pengereman secara elektris adalah mekanisme membuat torsi perlambatan untuk menghentikan motor baik secara langsung perlahan-lahan, tergantung dari kebutuhan sistem. Dengan kata lain pengereman adalah penghilang energi kinetik yang bekerja pada motor [1]. Salah satu bahan semikonduktor organik yang sering digunakan adalah pentacene karena ketersediaannya dan kinerja divaisnya [4]. Material organik telah menjadi perhatian para peneliti meskipun karakternya kurang dari silikon [5]. Dengan adanya Internet of Things dapat memudahkan pengguna saat mengakses atau menggunakan piranti yang berada pada jarak jauh [6]. Semakin pesatnya perkembangan dunia otomotive khususnya kendaraan roda 4 atau yang sering kita sebut mobil, mendorong para produsen kendaraan mobil ini untuk berinovasi mengembangkan teknologi pada kendaraan yang di produksi [7]. Energi sangat penting untuk manusia untuk bisa bertahan hidup [8]. Dalam perkembangan 
RESISTOR (Elektronika Kendali Telekomunikasi Tenaga Listrik Komputer) Vol. 3 No. 1 e-ISSN : 2621-9700, p-ISSN : 2654-2684

teknologi saat ini, listrik menjadi salah satu kebutuhan yang sangat penting bagi kehidupan masyarakat, baik dalam rumah tangga maupun dalam bidang industri [9]. Saat ini, perkembangan dunia teknologi yang demikian mengagumkan itu telah membawa manfaat yang luar biasa bagi kemajuan peradaban umat manusia [10]. Energi matahari dimanfaatkan sebagai sumber energi alternatif yang potensial [11]. Pada perkembangan teknologi saat ini perusahaan - perusahaan semakin gencar untuk mendatangkan mesin - mesin dengan teknologi - teknologi cangih dan modern, sehingga perusahaan pun semakin ketat untuk dapat menghasilkan produk - produk dengan kualitas dan mutu yang baik dan tepat sasaran serta efektif dan efesien [12]. Sumber energi fosil seperti minyak bumi, gas alam dan batubara akan bisa bertahan jika sumber energi terbarukan digunakan [13]. Termoelektrik adalah fenomena di mana energi panas diubah menjadi listrik dan sebaliknya [14]. Penjelasan mengenai pengereman dinamis telah dibahas dengan baik pada penelitian sebelumnya [15], namun belum dibahasa secara rinci mengenai prakteknya. Kemudian simulasi pengerman dinamik juga telah dibahas dengan baik pada penelitian sebelumnya [16], tapi belum dibahas mengenai penggabungan dua metode pengerman dinamik. Pengereman dicapai dalam empat tahap menggunakan sirkuit switching elektronik. Awalnya, satu kapasitor terhubung di dua terminal motor yang memungkinkan fase tunggal diri perangsangan [17]. Pengereman motor induksi tiga fase diperlukan dalam banyak aplikasi industri [18]. Motor induksi sangkar tupai tiga fase sebagian besar digunakan dalam driver industri karena mereka kasar, dapat diandalkan dan ekonomis [19]. Mempelajari proses pengereman di motor alternating current (AC) memiliki kepentingan besar karena kebutuhan untuk mengurangi waktu pengereman dan berhenti [20]. Pada penelitian ini akan dibahas mengenai perbandingan metode capacitor self excitation, zero sequence braking dengan inject tegangan $\mathrm{AC}$ dan mengkombinasikan dua metode pengereman tersebut yang dijalankan secara bergantian dalam momen pemberhentian motor yang sama.

\section{METODOLOGI}

Blok diagram ini adalah penelitian yang dibuat menggunakan objek motor induksi 3 fasa dengan sumber tegangan $380 \mathrm{~V}$. Kemudian pengereman dibuat menggunakan metode yang sudah ditentukan dan dari pengujian didapat waktu pengereman dan selanjutnya dianalisa berdasarkan hasil pengujian.

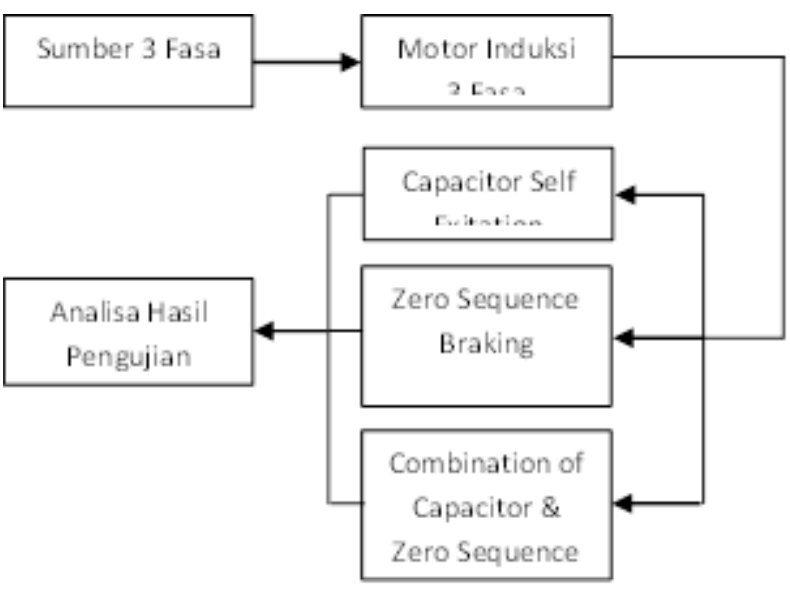

Gambar 1 Blok diagram rancangan penelitian.

Pada penelitian ini bertujuan untuk memahami metode pengereman motor induksi 3 fasa. Maka, diperlukan beberapa skema atau urutan penelitian agar penelitian lebih terarah dan mendapatkan hasil yang maksimal. Adapun skema metodologi yang akan digunakan ditunjukan pada gambar 3.2.

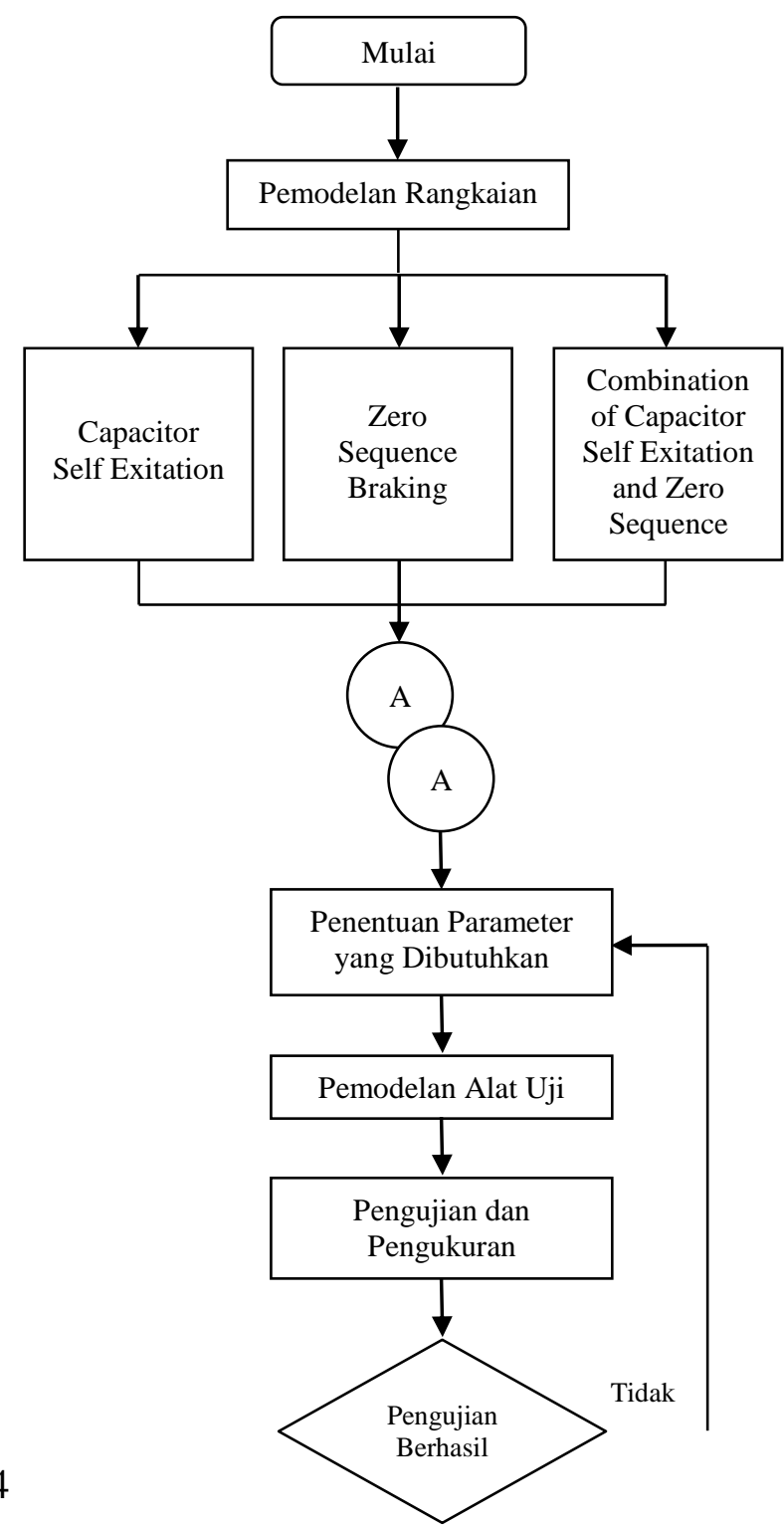


RESISTOR (Elektronika Kendali Telekomunikasi Tenaga Listrik Komputer) Vol. 3 No. 1 e-ISSN : 2621-9700, p-ISSN : 2654-2684

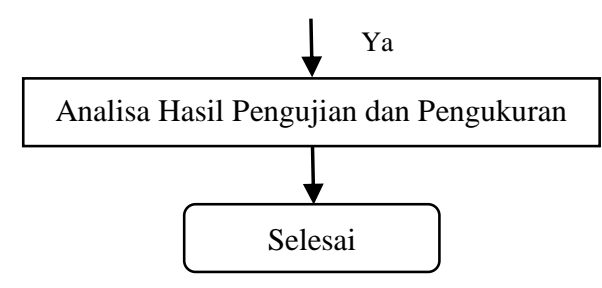

Gambar 2 Flowchart pengambilan data penelitian.

\section{HASIL DAN PEMBAHASAN}

. Perancangan alat pengereman motor induksi 3 fasa ini menggunakan kapasitor sebagai media untuk mempercepat pengereman motor dalam metode Capacitor Self Exitation, kemudian memanfaatkan putaran yang berlawanan dengan putaran motor dengan mencatu arus AC ke terminal stator yang dihubungkan secara seri dalam metode Zero Sequence Braking.

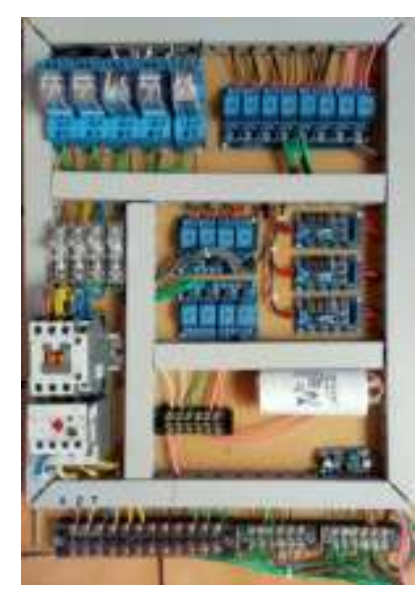

Gambar 3 Perancangan alat pengereman motor induksi 3 fasa.

Dalam melakukan penelitian ini akan digunakan objek yaitu motor induksi 3 fasa dengan spesifikasi seperti ditunjuk pada table 1.

Tabel 1 Spesifikasi motor induksi 3 fasa.

\begin{tabular}{|l|c|c|}
\hline Motor Brand & & Teco \\
\hline Country of Origin & & Taiwan \\
\hline Output Power & Watt & 1800 \\
\hline Speed & $\mathrm{Rpm}$ & 1500 \\
\hline Voltage & $\mathrm{Ph} / \mathrm{V} / \mathrm{Hz}$ & $3 / 380 / 50$ \\
\hline Type & & TEFC \\
\hline
\end{tabular}

Pengujian pertama yaitu lamanya waktu yang dibutuhkan untuk berhentinya motor rangkaian DOL tanpa pengereman selama 16,9 detik. Berdasarkan pengujian tanpa pengerem yang telah dilakukan, maka didapat hasil yang dilihat pada tabel 2 .

Tabel 2 Data hasil pengujian tanpa penereman.

\begin{tabular}{|c|c|}
\hline No & Waktu henti (detik) \\
\hline 1 & 16,9 \\
\hline
\end{tabular}

Pengujian kedua yaitu menggunakan metode Capacitor Self Exitation. Waktu yang dibutuhkan motor untuk berhenti yaitu menggunakan kapasitor $30 \mu \mathrm{F}$ selama 14 detik, $35 \mu \mathrm{F}$ selama 13,5 detik, $45 \mu \mathrm{F}$ selama 12 detik, dan $50 \mu \mathrm{F}$ selama 11,5 detik. Berdasarkan pengujian yang telah dilakukan pengereman dengan metode capacitor self exitation, maka didapat hasil yang dilihat pada tabel 3 .

Tabel 3 Data hasil pengujian pengereman capacitor self exitation.

\begin{tabular}{|c|c|c|}
\hline No & Nilai Kapasitor & Waktu henti (detik) \\
\hline 1 & $30 \mu \mathrm{F}$ & 14 \\
\hline 2 & $35 \mu \mathrm{F}$ & 13,5 \\
\hline 3 & $45 \mu \mathrm{F}$ & 12 \\
\hline 4 & $50 \mu \mathrm{F}$ & 11,5 \\
\hline
\end{tabular}

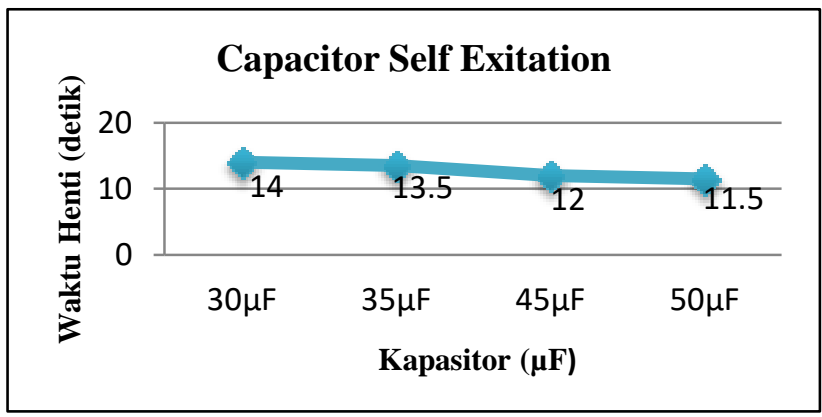

Gambar 4 Grafik pengereman capacitor self exitation.

Pengujian ketiga yaitu menggunakan metode Zero Sequence Braking. Waktu yang dibutuhkan motor untuk berhenti yaitu menggunakan inject AC 232 volt selama 13detik, 242 volt selama 11,9 detik, 252 volt selama 10,8 detik, dan 262 volt selama 9,9 detik. Hasil pengujian pengereman dengan metode zero sequence braking dapat dilihat pada tabel 4 . 
RESISTOR (Elektronika Kendali Telekomunikasi Tenaga Listrik Komputer) Vol. 3 No. 1 e-ISSN : 2621-9700, p-ISSN : 2654-2684

Tabel 4 Data hasil pengujian pengereman zero sequence braking.

\begin{tabular}{|c|c|c|}
\hline No & Arus AC & Waktu henti (detik) \\
\hline 1 & 232 volt & 13 \\
\hline 2 & 242 volt & 11,9 \\
\hline 3 & 252 volt & 10,8 \\
\hline 4 & 262 volt & 9,9 \\
\hline
\end{tabular}

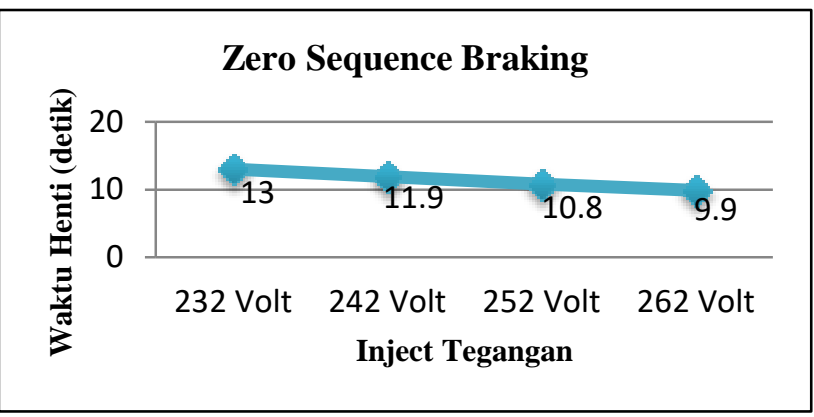

Gambar 5 Grafik pengereman zero sequence
braking.

Pengujian keempat yaitu menggunakan metode kombinasi antara 2 metode tersebut. Waktu yang dibutuhkan motor untuk berhenti yaitu menggunakan inject AC 234 volt, 244 volt, 254 volt, 264 volt dan kapasitor $30 \mu \mathrm{F}, 35 \mu \mathrm{F}, 45 \mu \mathrm{F}, 50 \mu \mathrm{F}$ dapat dilihat pada tabel 5 .

Tabel 5 Data hasil pengujian pengereman kombinasi.

\begin{tabular}{|c|c|c|c|c|c|}
\hline \multirow{2}{*}{ No } & \multirow{2}{*}{ Arus AC } & \multicolumn{4}{|c|}{ Waktu henti (detik) / Kapasitor } \\
\cline { 3 - 6 } & & $30 \mu \mathrm{F}$ & $35 \mu \mathrm{F}$ & $45 \mu \mathrm{F}$ & $50 \mu \mathrm{F}$ \\
\hline 1 & 234 Volt & 16 & 14 & 11,6 & 10,2 \\
\hline 2 & 244 Volt & 13,8 & 12,9 & 10,8 & 9,6 \\
\hline 3 & 254 Volt & 10,4 & 9,1 & 7,8 & 6,9 \\
\hline 4 & 264 Volt & 9,2 & 7,9 & 6,8 & 6,1 \\
\hline
\end{tabular}

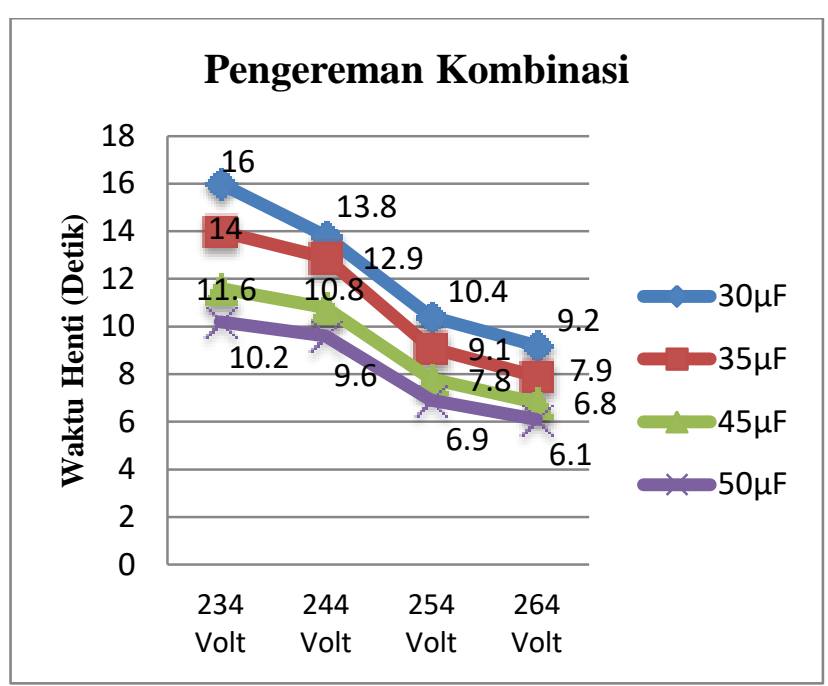

Gambar 6 Grafik pengereman kombinasi.

\section{KESIMPULAN}

Setelah melakukan pengujian dan Analisa maka hasil yang didapat sebagai berikut.

1. Pada metode Capacitor Self Exitation, terjadi penurunan waktu berhenti yang didapatkan dengan mengubah kapasitas dari kapasitornya. Semakin besar kapasitas kapasitor yang digunakan semakin cepat motor dapat berhenti. Waktu tercepat dalam menghentikan motor adalah dengan menggunakan $50 \mu \mathrm{F}$ dibutuhkan waktu 11,5 detik.

2. Pada Metode Zero Sequence Braking, terjadi penurunan waktu berhenti yang didapatkan dengan mengubah inject tegangan pada belitan stator. Semakin besar inject tegangan yang diberikan maka akan semakin cepat waktu yang didapat dalam melakukan pengereman motor. Waktu tercepat dalam menghentikan motor adalah dengan inject tegangan 262 volt dibutuhkan waktu 9,9 detik.

3. Pada pengerman kombinasi antara kedua metode tersebut, didapat penurunan waktu berhenti motor lebih cepat dibandingkan dengan hanya menggunakan satu metode. Semakin besar inject tegangan dan kapasitornya semakin cepat motor dapat berhenti. Pada percobaan ini rangkaian kombinasi lebih efektif dalam melakukan pengereman sisa putaran motor induksi 3 fasa. Waktu tercepat yaitu menggunakan inject

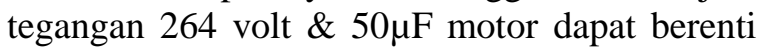
dalam waktu 6.4 detik.

\section{DAFTAR PUSTAKA}

[1] M. H. Pradipta, T. Sukmadi, and M. Facta, "Pengereman Dinamis Konvensional Pada Motor Induksi Tiga Fasa," Transient: Jurnal 
RESISTOR (Elektronika Kendali Telekomunikasi Tenaga Listrik Komputer) Vol. 3 No. 1 e-ISSN : 2621-9700, p-ISSN : 2654-2684

Ilmiah Teknik Elektro, vol. 3, no. 4, pp. 656663, 2015.

[2] A. Jaya and E. Wahjono, "SISTEM PENGEREMAN REGENERATIVE MENGGUNAKAN KAPASITOR PADA MOTOR LISTRIK BERPENGGERAK MOTOR INDUKSI TIGA FASA," presented at the Prosiding Seminar RiTekTra, 2014, p. 6.

[3] M. F. Yusron, "Pengereman Dinamik Motor Induksi 3 Fase 220V/380V," INAJEEE: Indonesian Journal of Electrical and Eletronics Engineering, vol. 1, no. 1, pp. 1923, 2018.

[4] F. Fadliondi, M. Kunta Biddinika, and S. I. Omi, "The Humidity Dependence of Pentacene Organic Metal-OxideSemiconductor Field-Effect Transistor.," Telkomnika, vol. 15, no. 2, 2017.

[5] F. Fadliondi, H. Isyanto, and P. G. Chamdareno, "The comparison of organic field effect transistor (OFET) structures," in 2017 2nd International Conference on Frontiers of Sensors Technologies (ICFST), 2017, pp. 6-9.

[6] H. Isyanto and A. Nandiwardhana, "Perancangan DC Cooler Berbasis Internet of Things," RESISTOR (elektRonika kEndali telekomunikaSI tenaga liSTrik kOmputeR), vol. 2, no. 2, pp. 95-104, 2019.

[7] S. Bahri and P. S. Yuza, "Analisa Kerusakan (Deformasi) Engine Mounting Kendaraan Toyota Agya Berdasarkan Tingkat Vibrasi Berbasis Mem Accelerometer," RESISTOR (elektRonika kEndali telekomunikaSI tenaga liSTrik kOmputeR), vol. 2, no. 2, pp. 131-136, 2019.

[8] B. Budiyanto and F. Fadliondi, "The Improvement of Solar Cell Output Power Using Cooling and Reflection from Mirror," International Journal of Power Electronics and Drive Systems, vol. 8, no. 3, p. 1320, 2017.

[9] E. Dermawan, P. G. Chamdareno, and A. R. Priyono, "Studi Analisa Start-Up Gas Turbin Memanfaatkan Generator Utama sebagai Motor Penggerak Mula dengan Menggunakan Static Frequency Converter (Sfc) pada Unit Blok 1-2 PT. PJB Unit Pembangkitan Muara Tawar," RESISTOR (elektRonika kEndali telekomunikaSI tenaga liSTrik kOmputeR), vol. 2, no. 2, pp. 83-88, 2019.
[10] H. Muchtar and F. Said, "Sistem Identifikasi Plat Nomor Kendaraan Menggunakan Metode Robert Filter dan Framing Image Berbasis Pengolahan Citra Digital," RESISTOR (elektRonika kEndali telekomunikaSI tenaga liSTrik kOmputeR), vol. 2, no. 2, pp. 105-112, 2019.

[11] D. Almanda and B. P. Piliang, "Perbandingan Sistem Pendingin pada Konsentrasi Water Coolant, Air Mineral, dan Air Laut Menggunakan Panel Surya Fleksibel Monocrystaline 20 Wp," RESISTOR (elektRonika kEndali telekomunikaSI tenaga liSTrik kOmputeR), vol. 2, no. 2, pp. 73-82, 2019.

[12] R. Samsinar, D. Almanda, and E. Priatna, "Sistem Pengingat Ganti Oli Berdasarkan Running Hours Mesin, Lama Waktu Pemakaian dan Kekentalan Oli pada Mesin Wire Drawing Berbasis Raspberry Pi 1," RESISTOR (elektRonika kEndali telekomunikaSI tenaga liSTrik kOmputeR), vol. 2, no. 2, pp. 121-130, 2019.

[13] F. Fadliondi, H. Isyanto, and B. Budiyanto, "Bypass Diodes for Improving Solar Panel Performance," International Journal of Electrical and Computer Engineering, vol. 8, no. 5, p. 2703, 2018.

[14] F. Fadliondi, B. Budiyanto, H. Isyanto, and P. G. Chamdareno, "Effects of Several Parameters on Thermoelectricity," vol. 62, no. 02, p. 6, 2020.

[15] P. L. Rongmei, S. L. Shimi, D. S. Chatterji, and V. K. Sharma, "A novel fast braking system for induction motor," International Journal of Engineering and Innovative Technology (IJEIT) Volume, vol. 1, 2012.

[16] S. C. Buana, T. Sukmadi, and M. Facta, "PENGEREMAN DINAMIK BERTINGKAT UNTUK MOTOR INDUKSI TIGA FASA," TRANSIENT, vol. 5, no. 3, pp. 287-292, 2017.

[17] S. S. Murthy, G. J. Berg, C. S. Jha, and A. K. Tandon, "A novel method of multistage dynamic braking of three-phase induction motors," IEEE transactions on industry applications, no. 2, pp. 328-334, 1984.

[18] M. M. Elkholy and M. A. Elhameed, "Braking of Three Phase Induction Motors by Controlling Applied Voltage and Frequency Based on Particle Swarm Optimization Technique," International Journal of Power 
RESISTOR (Elektronika Kendali Telekomunikasi Tenaga Listrik Komputer) Vol. 3 No. 1 e-ISSN : 2621-9700, p-ISSN : 2654-2684

Electronics and Drive Systems, vol. 5, no. 4, p. 520, 2015.

[19] M. Rata and G. Rata, "Study solution of induction motor dynamic braking," in 2016 International Conference on Development and Application Systems (DAS), 2016, pp. 33-37.

[20] M. S. Alshamasin, "Control of zero sequence braking for a three-phase induction motor operating from single-phase supply with a controlled capacitor," Journal of Applied Sciences, vol. 12, no. 24, pp. 2616-2620, 2012. 